\title{
CLEPTOPARASITISM OF AMMOPHILA HARTI \\ (FERNALD) (HYMENOPTERA: SPHECIDAE) \\ BY SENOTAINIA VIGILANS ALLEN, WITH \\ OBSERVATIONS ON PHROSINELLA AURIFACIES \\ DOWNES (DIPTERA: SARCOPHAGIDAE)*
}

\author{
By Barbara J. Hager and Frank E. Kurczewski \\ Department of Environmental and Forest Biology, \\ S.U.N.Y. College of Environmental Science and Forestry, \\ Syracuse, New York 13210
}

\section{INTRODUCTION}

Cleptoparasites utilize a host's food or prey for the rearing of their own young (Evans, 1970; Matthews and Matthews, 1978). They are often an integral part of fossorial and xylicolous solitary wasp nesting aggregations and, as such, have been reported in the wasp literature for many years (e.g., Peckham and Peckham, 1898; Fabré, 1916; Rau and Rau, 1918; Ristich, 1953, 1956; Evans, 1963, 1966, 1970; Kurczewski and Harris, 1968; Peckham, 1977; Evans, et al., 1980; Wcislo, 1984). Some of the more important cleptoparasites belong to the tribe Miltogrammini (Diptera: Sarcophagidae) (Allen, 1926; Evans, 1970), and these may be grouped into two categories based on their manner of host-location: (1) hole searchers and (2) satellite flies (Ristich, 1956; Evans, 1970). Regardless of which host-locating method is employed, cleptoparasites place an environmental pressure on the reproduction of the wasps. Wasps can reduce the deleterious effects of cleptoparasitism by evolving effective counter-cleptoparasitic behaviors (see Spofford, et al., 1986). Progressive provisioning of nests, in which the female wasp provides food to the larva over a period of days and therefore comes into close contact with her developing young, is believed to have evolved in part as a response to cleptoparasitism (Evans, 1966, 1970; Evans and Eberhard, 1970).

Ammophila harti (Fernald), a simultaneous progressive provisioner, was found in association with two miltogrammine cleptoparasites, Senotainia vigilans Allen and Phrosinella aurifacies

*Manuscript received by the editor April 24, 1985. 
Downes. This provided us with the opportunity to examine: (1) the effects of cleptoparasitism on the reproductive success of a progressive provisioner; (2) the behavioral strategies of the flies in attempting to parasitize $A$. harti nests; (3) the actual means by which cleptoparasitism is reduced; and, (4) the behavioral responses of $A$. harti to the presence of the flies.

\section{Study Site AND Methods}

The study was conducted near Auburn, Cayuga County, NY, between 2 June-29 Aug 1982 and 21 June-22 Aug 1983. A description of the site is given elsewhere (Hager and Kurczewski, 1985, 1986). The behavior of $P$. aurifacies and $S$. vigilans was recorded in order to obtain average hourly, daily and seasonal activity rates. These rates are reported in mean number observed behaviors/sample $\mathrm{hr}$ to account for differences in sampling effort. The data for the two years are pooled. To provide greater biological significance, calendar date is adjusted to reproductive date with reproductive date 1 corresponding to the first day of $A$. harti nesting activity.

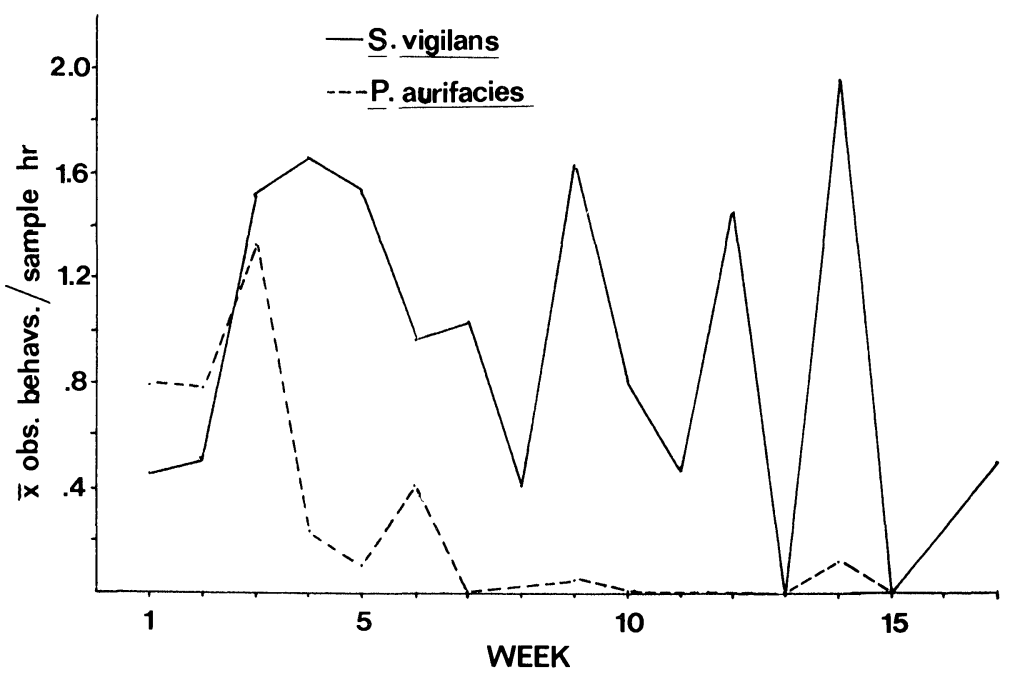

Figure 1. Weekly activity (mean no. observed behaviors/sample hr) of Senotainia vigilans and Phrosinella aurifacies in Ammophila harti nesting aggregation, combined for 1982 and 1983 . Week 1 corresponds to first week of $A$. harti nesting. 
The cleptoparasitic behavior of $S$. vigilans was divided into two categories: (1) landing on the prey and (2) entering nests. A. harti's response to the presence of this fly was observed and classified as: (1) no response (wasp continued to normally provision the nest) or (2) response (wasp deviated from her normal provisioning pattern). We observed the following responses: (1) freeze-stop (Alcock, 1975), (2) flight, (3) prey abandonment, and (4) nest cleaning.

Nests suspected of being parasitized were excavated within 24-48 $\mathrm{hr}$ of the observed fly activity and the rates of parasitism determined. Wasp larvae and fly maggots were removed from nests and placed in sand-filled, plastic $35 \mathrm{~mm}$ film canisters to simulate the cell environment. Larvae and maggots were fed quiescent caterpillars taken from provisioning females or obtained from nearby vegetation and killed by freezing. Overwintering puparia and cocoons were placed in perforated containers in a punctured bucket (to allow drainage) and buried in the sand at approximately the mean cell depth of $A$. harti. The bucket was removed in March and brought into the lab to obtain emergence records.

\section{RESULTS}

\section{Phrosinella aurifacies}

$P$. aurifacies was most active during June and July in association with the first generation of $A$. harti (Fig. 1). There was a sharp decline in $P$. aurifacies activity as the season progressed (ANOVA $\left.\mathrm{F}=12.43,14 \mathrm{df}, \mathrm{p}<0.01, \mathrm{r}^{2}=0.45\right)$. A few flies were observed sporadically in August and September. Daily activity of $P$. aurifacies during the first generation of $A$. harti was uniformly distributed (Fig. 2).

$P$. aurifacies was observed walking circuitously on the tumuli of $A$. harti nests. The flies investigated any disturbed sand areas, including entrances to other wasp nests and footprints. No larviposition was observed in an $A$. harti nest entrance or in or on the tumulus, nor were any maggots or puparia found in or near the cell of an excavated nest. Only one fly was observed exiting an open $A$. harti nest. When dug the next day, the cell of this nest was empty and no evidence of flies was found in its vicinity. A. harti occasionally chased away flies circling on tumuli of nests under construction.

The abundance of $P$. aurifacies during the first generation coincided with the construction of the deepest $A$. harti cells. Regression 
analysis between $P$. aurifacies activity and cell depth yielded an $\mathrm{r}^{2}$ value of 0.42 (ANOVA $F=10.28, \mathrm{p}<0.01)$.

\section{Senotainia vigilans}

$S$. vigilans was present throughout the nesting season of $A$. harti (Fig. 1). During the first generation of $A$. harti, S. vigilans was more active in the morning than in the afternoon (Fig. 2). This coincided with the period of greatest activity of first generation females of $A$. harti and other wasps present in the sand pit. In the second generation of $A$. harti, $S$. vigilans was equally active in both the morning and afternoon (Fig. 2).

$S$. vigilans was attracted to movement and, therefore, trailed wasps constructing, inspecting, or provisioning nests. Flies either hovered $2-15 \mathrm{~cm}$ above and behind a female while darting close to the wasp or her prey, or perched on a nearby elevated site (e.g., pebble, plant) and watched the wasp from there. In attempting to larviposit on the prey, $S$. vigilans exhibited two, not mutually exclusive, behaviors: (1) landing on the prey at the nest entrance or as it was being taken inside; and (2) entering the nest (following the provisioning wasp into a nest). (see Spofford, et al., 1986.)

Of 105 observations of $S$. vigilans attracted to $A$. harti provisioning their nests, flies landed on the prey $25.7 \%$ (27 of 105) of the time. Some $S$. vigilans landed and larviposited on prey during transport to the nest, but most landed on the prey either while the wasp was opening the nest or as she took the prey inside.

Flies entered the wasps' burrows $47(44.8 \%)$ times. It was uncertain whether or not entering flies larviposited on the prey or in the burrow, or left without larvipositing. Some flies did not travel far into the burrow and most reappeared less than $2 \mathrm{sec}$ after entry. Two flies reappeared in entrances shortly after the wasps, indicating that they had "crossed paths" in the burrow. Flies attracted to provisioning $A$. harti did not attempt to larviposit $29.5 \%$ (31 of 105) of the time. These flies either continued to hover, were distracted by another wasp in the vicinity, or were eluded by the wasp (see counter-cleptoparasitic behavior).

The success frequency of the "landing" strategy was high (Table 1). Larviposition occurred 20 of $27(74.1 \%)$ times when the fly landed on the prey. It could not be ascertained if larviposition actually occurred when a fly entered the nest because the fly was not visible. Therefore the presumed parasitism numbers $(\approx$ success fre- 


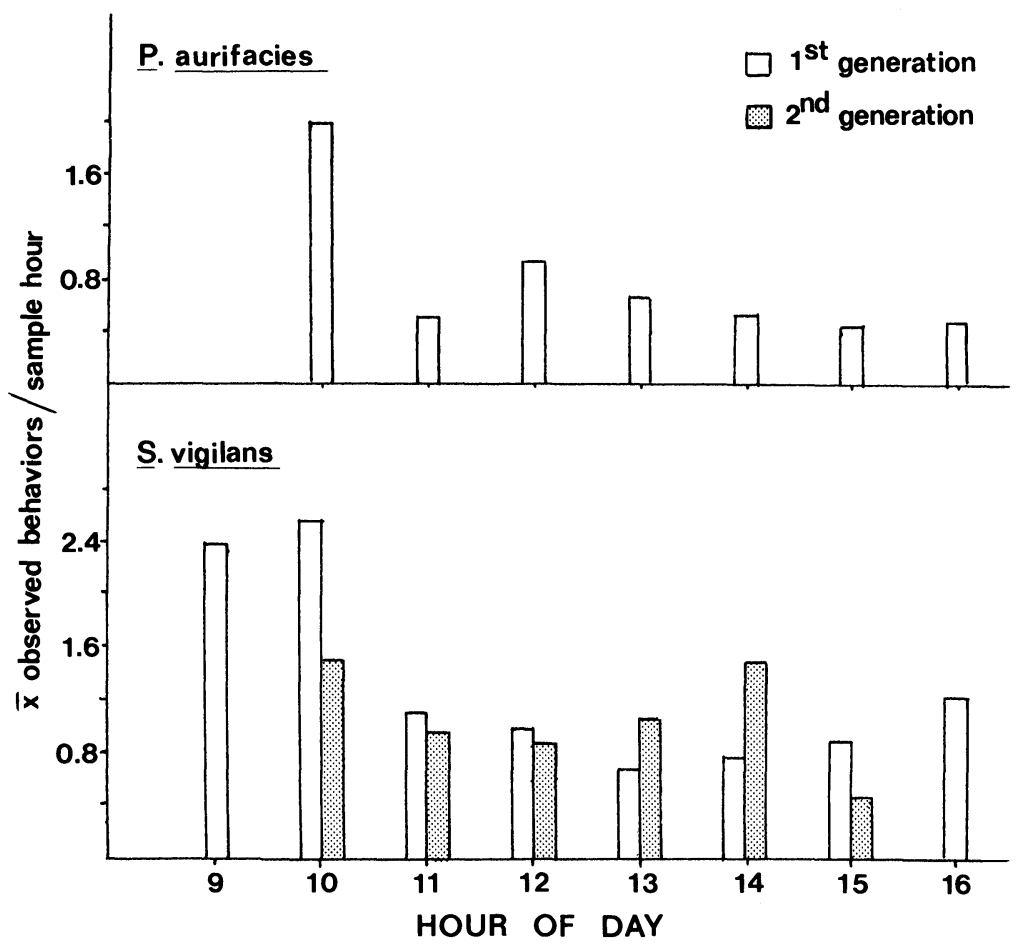

Figure 2. Hourly activity of Senotainia vigilans and Phrosinella aurifacies during first and second generations of Ammophila harti, combined for 1982 and 1983. There are no data for $P$. aurifacies during $A$. harti's second generation due to low population.

quency) for the entering behavior may not reflect actual larviposition. A nest that contained decaying prey remains and/or puparia near the cell was presumed to have been parasitized and those in which a maggot or maggots were found were obviously parasitized.

Four larvipositions by $S$. vigilans were successful when the attack occurred on the initial prey placed in the cell. None of the 16 attacks which occurred on a subsequent provisioning of a nest were successful. If entering behavior is included, the success frequency of cleptoparasitism on first provisioning drops to $72.7 \%$ (8 of 11) and successful attacks on subsequent provisioning increases to $7.1 \%$ ( 2 of 28 ). In total, only $25.6 \%$ of the attacks resulted in successful 
parasitism (10 of 39). When all of the nests constructed by females in which a prey was placed $(\approx$ used nests; see Hager and Kurczewski, 1986 ) are considered, $S$. vigilans successfully parasitized $1.63 \%$ (4 of 245 ) of the nests, while another $2.45 \%$ (6 of 245) of the nests were presumed parasitized, making a total of $4.08 \%$ (10 of 245) parasitized used nests.

Of eight $A$. harti cells containing $S$. vigilans maggots, three each also contained a wasp larva, four had prey only, and one cell contained two maggots and prey. From the nests with prey only, two flies emerged the following June and three others failed to emerge. In the cells also containing a wasp larva, the maggots disappeared within a day. Either the wasp larva consumed the maggot(s) or it outcompeted the maggot(s), resulting in its(their) starvation. One wasp larva actively moved from a fresh prey on which it was feeding to a prey that was parasitized. Three hr later, the maggot could not be found.

\section{Counter-cleptoparasitic behavior}

A provisioning wasp responded to the presence of an $S$. vigilans by either "freezing" on the sand for up to $10 \mathrm{~min}(\overline{\mathrm{x}}=4.3 \pm 3.6 \mathrm{~min}$, $\mathrm{N}=9$ ), flying to surrounding vegetation for up to $15 \mathrm{~min}(\overline{\mathrm{x}}=6.6 \pm$ $5.2 \mathrm{~min}, \mathrm{~N}=13$ ), or alternating periods of "freezing" with low hopping flights near her nest. $A$. harti sometimes turned and faced $S$. vigilans before freezing. At other times, the wasp would fly at the trailing flies. Success of "freezing" depended upon the number of flies present and the number of active wasps in the vicinity. In periods of high nesting density and activity, flies were easily distracted by the movements of other wasps and "freezing" was effective. Flights to vegetation were successful for the same reason.

Prey abandonment was observed once under continuous pressure from five trailing $S$. vigilans. Unsuccessful in evading the flies (several landed on the prey), the wasp crawled up vegetation and abandoned her prey. She proceeded to her nest, opened it, searched for her prey, but never relocated it. Six $S$. vigilans and a hyperparasite, Perilampus hyalinus Say (Perilampidae), were reared from this prey (see Spofford and Kurczewski, 1984).

Another response by $A$. harti to the presence of $S$. vigilans was nest cleaning (see Hager and Kurczewski, 1986). The number of times a wasp entered and removed sand from her burrow was a function of her activity (inspecting or provisioning) and the absence 
or presence of cleptoparasitic flies. In the absence of flies, the mean number of trips into the burrow for sand removal was $4.7 \pm 4.51$ (range 1-26, $\mathrm{N}=94$ ). With flies present, either hovering behind or perching nearby, the intensity of the cleaning behavior increased significantly to $9.5 \pm 4.97$ trips (range $1-17, \mathrm{~N}=23 ; \mathrm{t}=52.28,115$ $\mathrm{df}, \mathrm{p}<0.05)$.

\section{Discussion}

The main advantage of progressive provisioning is generally considered to be the greater protection from enemies afforded the egg or larva due to the prolonged presence of the female (Evans, 1966). The female may remove or destroy cleptoparasites or provide more food to a parasitized nest and thus prevent starvation of the larva. Since most provisioning trips to a nest occur after the egg has hatched, the cleptoparasite will usually be introduced to a larva. In this case, the larva may be able to outcompete the maggot (cleptoparasite) and thus indirectly kill it, or it may directly destroy the maggot by feeding upon it.

With this in mind, we can now consider several predictions for the effects of cleptoparasitism on $A$. harti: (1) cleptoparasites will almost always be successful if they attack the initial prey in a cell (while the wasp is still in the egg stage); (2) successful cleptoparasitism should decrease as the larva matures; and, (3) the larva may be the essential component in cleptoparasitic defense by consuming or outcompeting the maggot (cleptoparasite).

$P$. aurifacies, a closed nest searcher, had little or no effect on the reproductive success of $A$. harti. Cells were found to be deeper in the first generation when $P$. aurifacies was present, but the significance of this correlation remains questionable. Other factors (e.g., soil moisture) may influence cell depth. Reasons for why hole-searching cleptoparasites are not successful in parasitizing $A$. harti include: (1) the stone used to close the nest entrance provides a physical barrier to a burrowing maggot deposited in the entrance; (2) removal of the tumulus from the vicinity of the entrance may aid in its concealment and therefore $P$. aurifacies may be unable to detect (locate) the entrance; and, (3) $A$. harti cleans the burrow and, in so doing, may remove any maggots placed therein.

Senotainia vigilans, on the other hand, had limited success in cleptoparasitizing $A$. harti nests. This success depended upon the 


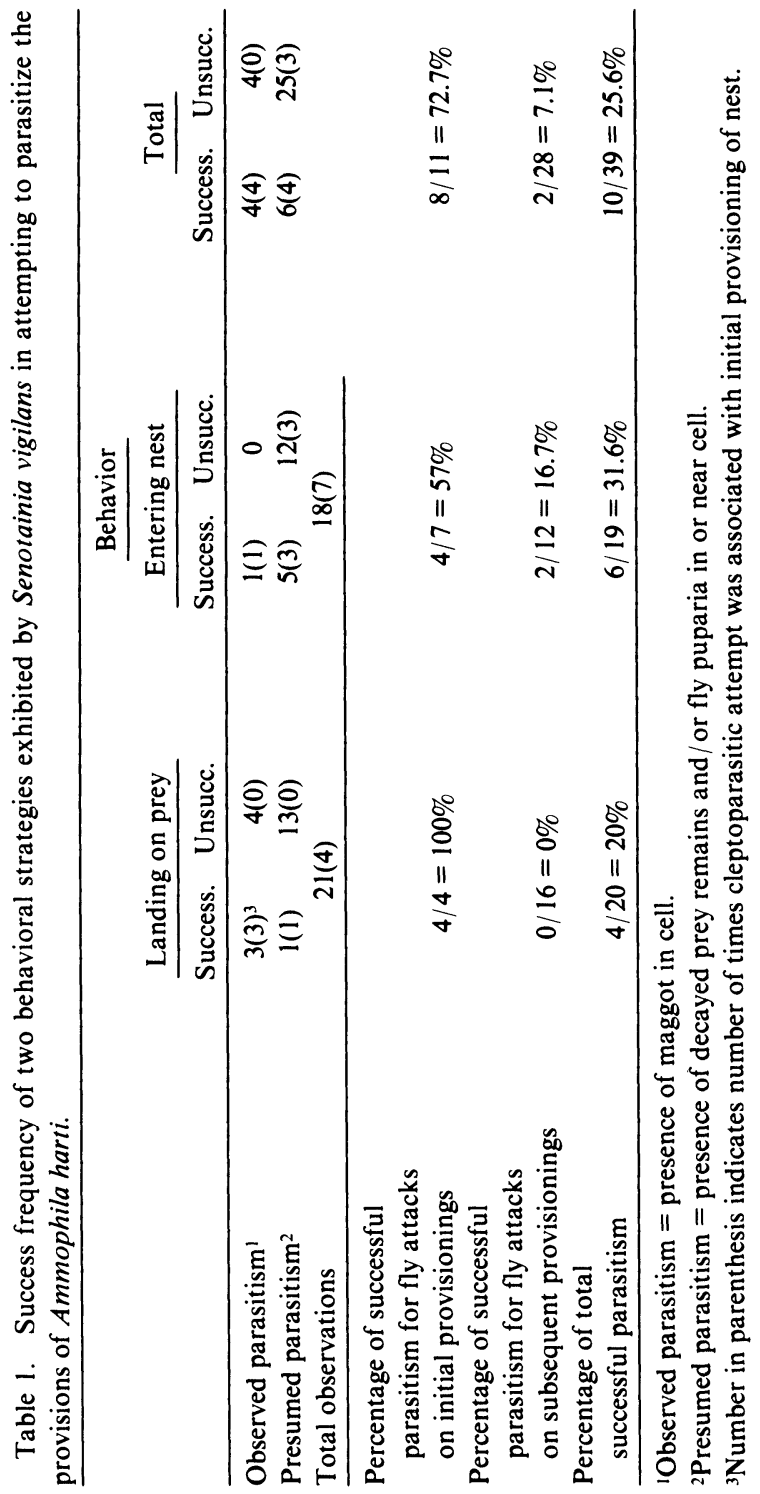


stage of the developing wasp at the time of maggot deposition; eggs and young larvae were most vulnerable (Table 1). The two nests presumed parasitized that were attacked after an initial provisioning may have contained young larvae.

In an attempt to test whether the female or the larva is responsible for the elimination of maggots after their introduction into a nest, four cells each containing a larva and maggot(s) were placed in individual rearing tins, thereby removing any influence the mother may have had on the cleptoparasitized nest. All of the maggots disappeared within hours, regardless of whether any extra prey were added to a cell. This suggests that the larva either starves the maggot indirectly by consuming the food or eats the maggot. One advantage of progressive provisioning in $A$. harti therefore appears to be the larva's ability to outcompete the cleptoparasite. The mother's ability to defend her larvae against cleptoparasitism may play a lesser role. Evans $(1966,1970)$ has noted in Bembix belfragei Cresson the cooccurence of larva and maggots, all of which were able to reach maturity by feeding on prey provided by the female.

The total frequency of successful cleptoparasitism of used nests was $4.08 \%$. If all of the provisioned nests found empty or with remains are considered to have been cleptoparasitized (which is highly unlikely), then $20 \%$ of the nests were cleptoparasitized. This is compared to the $57.9 \% \mathrm{~S}$. vigilans parasitism of a mass provisioner, Tachysphex terminatus (F. Smith), at the same site (Spofford, et al., 1986). Evans (1966) did not report any quantitative data on cleptoparasitic loads for progressive provisioning Nyssoninae but did note that cleptoparasitism was less than that for mass provisioners of this subfamily. Although cleptoparasitic frequencies for other wasps are scarce, the pattern still emerges that those species not exhibiting progressive provisioning suffer a higher cleptoparasitism-from 20\% [Philanthus zebratus nitens Cresson (Evans, 1970)] to 50\% [Sphecius speciosus (Drury) (Reinhard, 1929; Evans, 1966)].

Behavioral adaptations other than the manner of provisioning may also reduce cleptoparasitism. Nests may be provisioned at times of the day or season different from the diurnal and seasonal activity patterns of the flies. Such rhythmical modification is not well documented. Evans et al. (1980) found Crabro monticola (Packard) and Crabro largior Fox bringing prey to their nests early 
in the morning, before satellite flies were active. Certain pompilids and sphecids are less afflicted than related species because they overwinter in the adult stage and nest during the first warm spring days when few or no cleptoparasites are present (O'Brien and Kurczewski, 1982; Alm and Kurczewski, 1984). There was no daily or seasonal adjustment in provisioning times by $A$. harti related to peak fly activity. $S$. vigilans is a generalized cleptoparasite and many other fossorial wasp species were present at the study site.

Diversionary provisioning flights may be a means of deterring trailing satellite and related flies (Evans, 1963, 1970; Alcock, 1975; Matthews et al., 1979; Evans, et al., 1980, McCorquodale, 1984). Female wasps may perform elaborate flight manuevers incapable of being followed by the flies, they may take a long time in reaching the nest which may result in the fly losing interest, or they may freeze in a populated area and the fly may become distracted by another wasp. The latter two behaviors were observed frequently in $A$. harti. $A$. harti may exhibit these behaviors more often when initially provisioning a nest or when provisioning a young larva than when provisioning an older larva, but our data are insufficient to support this. Wasp species exhibiting progressive provisioning may not have evolved elaborate diversionary flights or other such "pre-parasitic" behaviors because of the ability of their larvae to outcompete maggots introduced into the cells ("post-parasitic" behavior).

Nest cleaning may be designed to rid the burrow of cleptoparasites. It is possible that $S$. vigilans larviposits after it enters the burrow and the maggot may then crawl downward into the cell. However, it is more plausible that the fly is attempting to contact the prey as it is carried down the burrow, based upon the behavior observed above ground. Burrow cleaning may remove any maggots so deposited. Evans (1966) observed debris being removed from nests of several Bembix species and suggested that this behavior prevents maggots from maturing on the excess food remains not consumed by the larva or may even remove maggots already present in the debris. The sand removed via the burrow cleaning of $A$. harti needs to be examined for the presence of maggots, although presence of maggots in the sand merely proves that $S$. vigilans will deposit maggots in the burrow and not that the function of burrow cleaning is to remove maggots. An alternative function of nest cleaning may be to facilitate the transport of prey to the cell by removing 
sand that might otherwise block the burrow. The presence of the adult fly may serve as a cue that stimulates further burrow cleaning. This then enables the wasp to bring the prey in more quickly during the next provisioning and decreases the exposure time of the prey to cleptoparasites.

Nesting in aggregations may reduce cleptoparasitism through the selfish herd effect (Wcislo, 1984). A. harti may nest in one location not only because it contains all of the physical requirements but also because those individuals nesting in a congested area may limit the amount of cleptoparasitism of their nests. Wcislo (1984) suggests that this works best against hole-searching cleptoparasites but we feel it can be extended to include satellite flies. $S$. vigilans was often distracted from following a provisioning wasp by the movements of another wasp nearby. A wasp adopting the strategy of remaining still after having been spotted by a satellite fly may have an increased chance of evading the fly when it is within a nesting aggregation.

\section{ACKNOWLEDGMENTS}

We thank N. E. Woodley and W. L. Downes, Jr. for identifying the flies, A. S. Menke for confirming the wasp species, and M. G. Spofford for assistance in the field. We also thank W. M. Shields for reviewing the manuscript and offering useful comments. This work was partly funded in 1982 and 1983 by Grants-in-Aid of Research from Sigma Xi, the Scientific Research Society.

\section{Literature Cited}

Alcock, J. 1975. The nesting behavior of Philanthus multimaculatus Cameron (Hymenoptera: Sphecidae). Am. Midl. Nat. 93: 222-226.

Allen, H. W. 1926. American species of two-winged flies belonging to the tribe Miltogrammini. Proc. U.S. Nat. Mus. 68: 1-106.

Alm, S. R. AND F. E. Kurczewski. 1984. Ethology of Anoplius tenebrosus (Cresson) (Hymenoptera: Pompilidae). Proc. Entomol. Soc. Wash. 86: 110-119.

Evans, H. E. 1963. The evolution of prey-carrying mechanisms in wasps. Evolution 16: $468-483$.

Evans, H. E. 1966. The comparative ethology and evolution of the sand wasps. Harvard Univ. Press, Cambridge, Mass., 526 pp.

Evans, H. E. 1970. Ecological-behavioral studies of the wasps of Jackson Hole, Wyoming. Bull. Mus. Comp. Zool. 140: 451-511. 
Evans, H. E. And M. J. W. Eberhard. 1970. The wasps. Univ. of Michigan Press, Ann Arbor, 265 pp.

Evans, H. E., F. E. Kurczewski, and J. Alcock. 1980. Observations on the nesting behaviour of seven species of Crabro (Hymenoptera: Sphecidae). J. Nat. Hist. 14: 865-882.

FABrE, J. H. 1916. The hunting wasps. Dodd, Mead, and Co., New York, N. Y., $427 \mathrm{pp}$.

Hager, B. J. AND F. E. Kurczewski. 1985. Reproductive behavior of male Ammophila harti (Fernald) (Hymenoptera: Sphecidae). Proc. Entomol. Soc. Wash. 87: 597-605.

Hager, B. J. AND F. E. Kurczewski. 1986. Nesting behavior of Ammophila harti (Fernald) (Hymenoptera: Sphecidae). Am. Midl. Nat. submitted.

KurCZEWSKi, F. E. AND B. J. Harris 1968. The relative abundance of two digger wasps, Oxybelus bipunctatus and Tachy'sphex terminatus, and their associates, in a sand pit in central New York. J. N. Y. Entomol. Soc. 76: 81-83.

Matthews, R. W., A. Hook AND J. W. KRispýn. 1979. Nesting behavior of Crabro argusinus and C. hilaris (Hymenoptera: Sphecidae). Psyche 86: 149-166.

Matthews, R. W. AND J. R. Matthews. 1978. Insect behavior. J. Wiley and Sons, Toronto, $507 \mathrm{pp}$.

McCorquodale, D. B. 1984. The provisioning flights of digger wasps (Hymenoptera: Sphecidae) as a defence against the nest parasite Senotainia trilineata (Diptera: Sarcophagidae). M.S. Thesis, Univ. of Alberta, 87 pp.

O'Brien, M. F. AND F. E. KurczewsKi. 1982. Ethology and overwintering behavior of Podalonia luctuosa (Hymenoptera: Sphecidae). Gr. Lakes Entomol. 15: $261-275$.

Peскнам, D. J. 1977. Reduction of miltogrammine cleptoparasitism by male Oxy'belus subulatus (Hymenoptera: Sphecidae). Ann. Entomol. Soc. Am. 70: 823-828.

Pecknam, G. W. and E. G. Pecknam. 1898. On the instincts and habits of the solitary wasps. Wisc. Geol. Nat. Hist. Survey, Sci. Ser., Bull. 2: 1-245.

Rau, P. and N. Rau. 1918. Wasp studies afield. Princeton Univ. Press, Princeton, N. J., 372 pp.

Reinhard, E. G. 1929. The witchery of wasps. The Century Co., New York, 291 $\mathrm{pp}$.

Ristich, S. S. 1953. A study of the prey, enemies, and habits of the great-golden digger wasp Chlorion ichneumoneum (L.) Can. Entomol. 85: 374-386.

Ristich, S. S. 1956. The host relationship of a miltogrammid fly Senotainia trilineata (VDW). Ohio J. Sci. 56: 271-274.

Spofford, M. G., ANd F. E. Kurczewsk I. 1984. A new host for Perilampus hyalinus Say (Hymenoptera: Perilampidae). Proc. Entomol. Soc. Wash. 86: 663.

Spofford, M. G., F. E. Kurczewski, and D. J. Peckham. 1986. Cleptoparasitism of Tachysphex terminatus (Smith) (Hymenoptera: Sphecidae) by three species of Miltogrammini (Diptera: Sarcophagidae). Ann. Entomol. Soc. Am. In press.

WCislo, W. T. 1984. Gregarious nesting of a digger wasp as a "selfish herd" response to a parasitic fly (Hymenoptera: Sphecidae; Diptera: Sarcophagidae). Behav. Ecol. Sociobiol. 15: 157-160. 

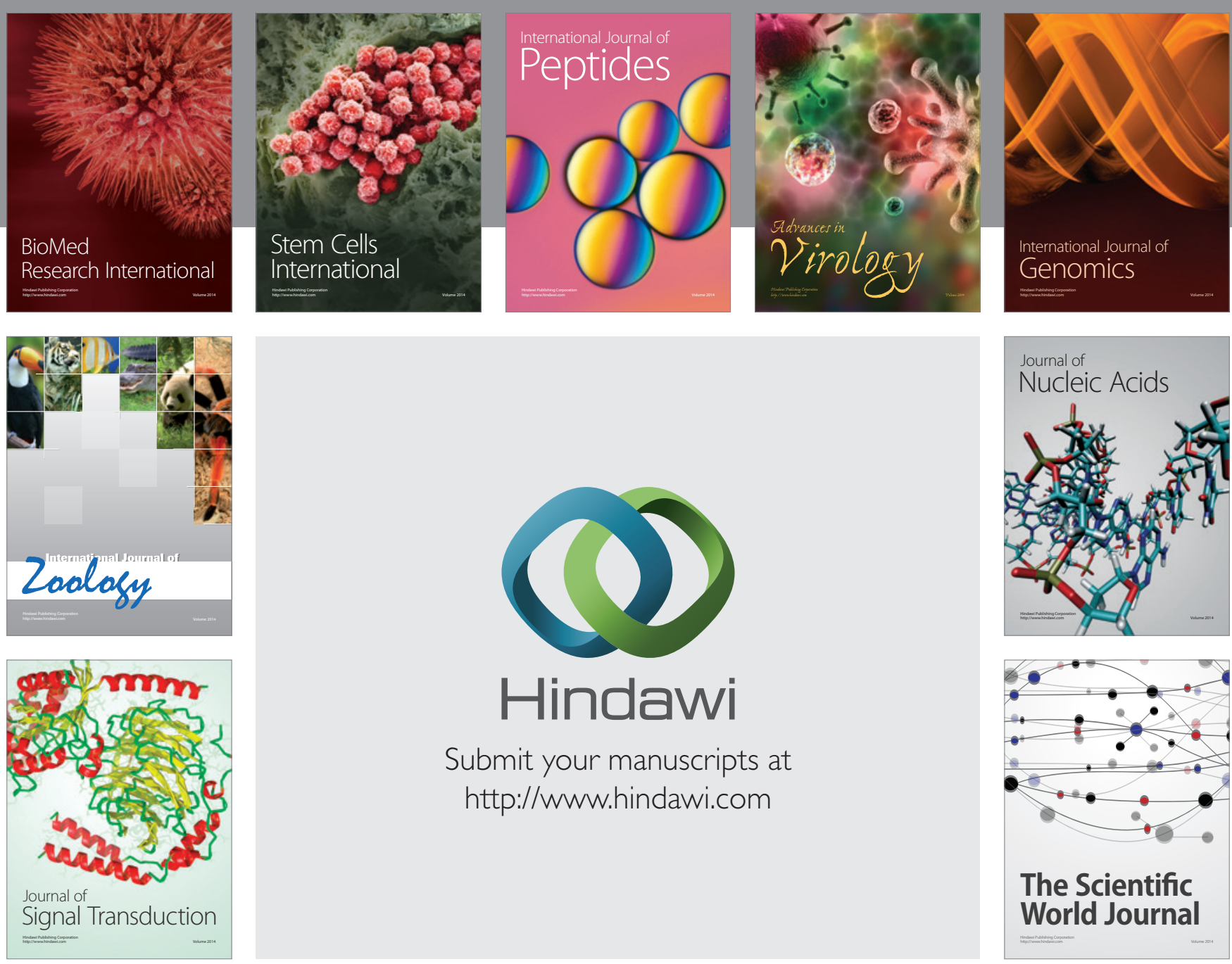

Submit your manuscripts at

http://www.hindawi.com
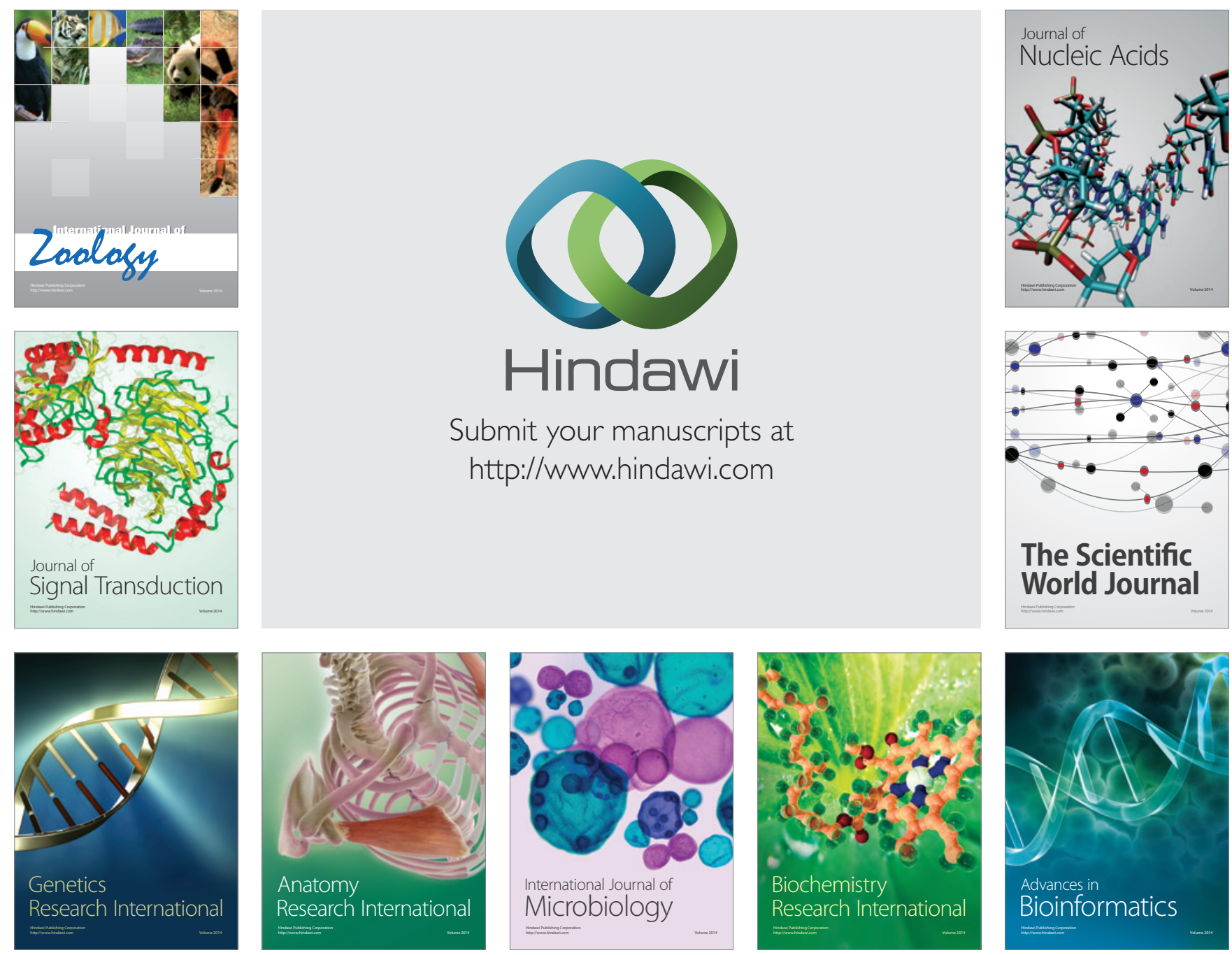

The Scientific World Journal
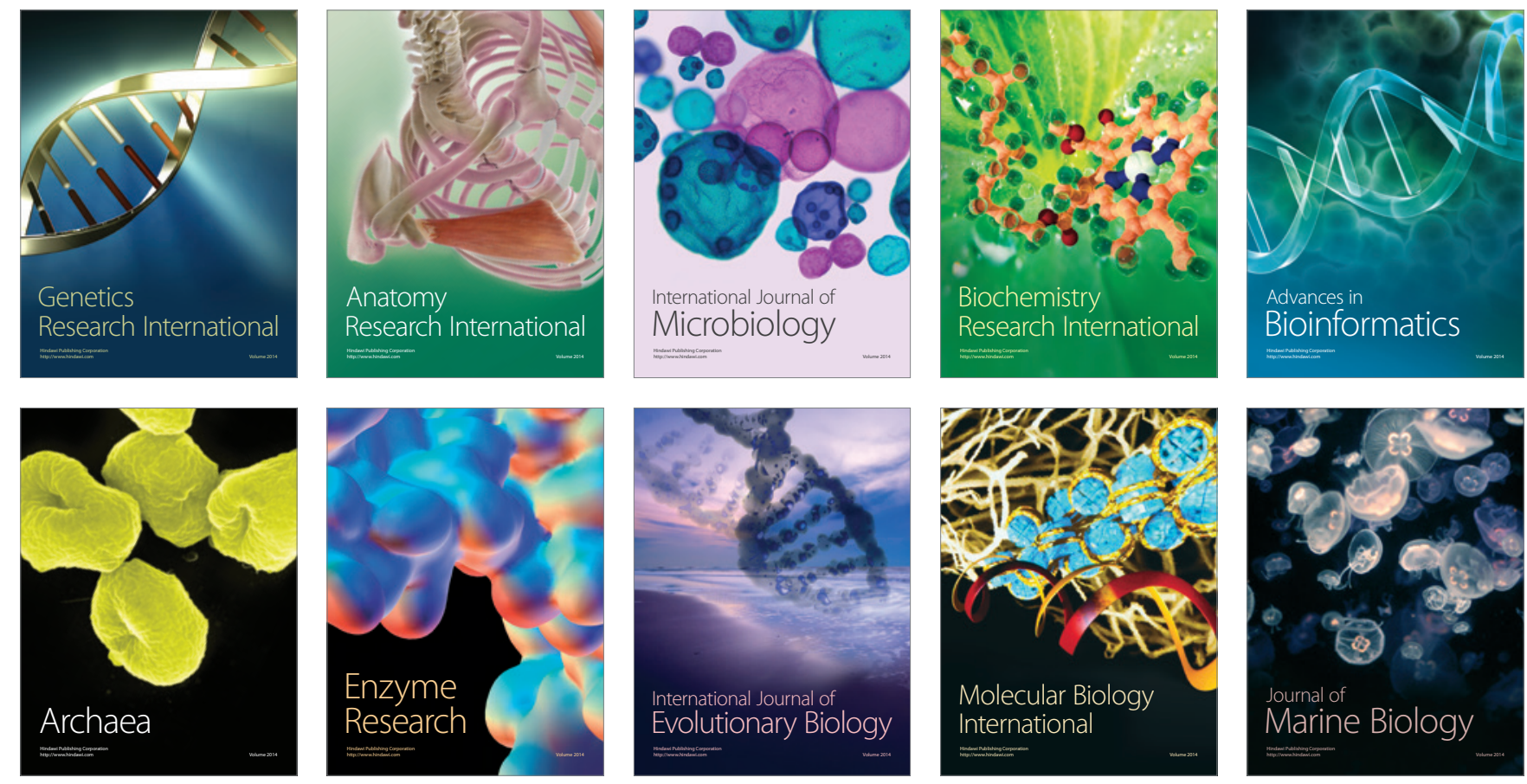